\title{
ANALISIS PUTUSAN HAKIM PRA PERADILAN PENGADILAN NEGERI BANGIL \\ NOMOR : 01/PID.PRA/2014/PN.BGL TGL 16 JUNI 2014 TERKAIT SURAT PERINTAH PENGHENTIAN PENYIDIKAN TINDAK PIDANA ZINA Jo PASAL 284 KUHP
}

\author{
Satriyo Rusdi \\ Program Magister Ilmu Hukum \\ Pascasarjana Universitas Islam Malang \\ Email : satriyorusdi1653@gmail.com
}

\begin{abstract}
Abstrak
Didalam Putusan Hakim Pra Peradilan Pengadilan Negeri Bangil nomor : 01/Pid.Pra/2014/PN.Bgl, tertanggal 16 Juni 2014, terkait Tindak Pidana Zina mengalami perluasan makna dan tidak lagi berpatokan sepenuhnya seperti sebagaimana dimaksud dalam Pasal 284 KUHP menurut penjelasan Soesilo dalam KUHP, Persetubuhan adalah : "Perpaduan antara anggota kelamin laki laki dan perempuan yang bisa dijalankan untuk mendapatkan anak, jadi anggota kelamin laki laki harus masuk kedalam anggota kelamin perempuan sehingga mengeluarkan air mani." Seiring berjalannya waktu perkembangan hukum mengalami perubahan sejak adanya putusan Mahkamah Agung RI no. 854/Pid/1983 yang berbunyi sebagai berikut : "seorang laki-laki terbukti telah bersama sama dengan seorang perempuan dalam satu kamar, pada satu tempat tidur merupakan petunjuk bahwa laki-laki itu telah bersetubuh dengan perempuan tersebut", akan tetapi pada akhirnya hakim Pra Peradilan Pengadilan Negeri Bangil , memutus perkara yang terkait dengan Tindak Pidana Zinah dengan tidak lagi mengacu pada satu kamar dan satu tempat tidur lagi, melainkan menjadi "seorang laki laki terbukti telah bersama sama dengan seorang perempuan tanpa ada ikatan perkawinan yang syah dan bukan suami istri, dalam satu rumah ( terdiri : 2 ruang kamar tidur, 1 ruang kamar mandi, 1 ruang makan dan 1 ruang tamu ) merupakan petunjuk bahwa laki laki tersebut "sudah dapat dianggap" telah bersetubuh dengan perempuan tersebut",
\end{abstract}

Kata kunci: pidana, zina, putusan, penyidikan

\begin{abstract}
In the Bangil District Court Pre-Court Judge's Decision number: 01 / Pid.Pra / 2014 / PN.Bgl, dated June 16, 2014, related to Adultery Crimes has expanded its meaning and is no longer fully regulated as referred to in Article 284 of the Criminal Code according to Soesilo's explanation in KUHP, intercourse is: "The combination of male and female genital members that can be carried out to have children, so male genital members must enter the female genitalia so that they release semen." Over time the development of law has changed since the ruling of the Indonesian Supreme Court no. 854 / Pid / 1983 which reads as follows: "a
\end{abstract}




\section{Zurnal Negara dan $\mathcal{X}$ eadilan \\ p-ISSN 2302-7010 e-ISSN 2721-9801}

man is proven to have been together with a woman in one room, in one bed is an indication that the man had had sex with the woman", but in the end the judge Pre The Bangil District Court, decided the case related to the Criminal Act of Zinah by no longer referring to one room and another bed, but to be "a man proven to have been together with a woman without any legal marital ties and not husband and wife, in one house (consisting of 2 bedrooms, 1 bathroom, 1 dining room and 1 living room) is an indication that the man "can be considered" having had sex with the woman ",

Keywords: criminal, adultery, verdict, investigation

\section{PENDAHULUAN}

Zina adalah setiap persetubuhan yang terjadi bukan karena pernikahan yang sah, bukan karena syubhat, dan bukan pula karena pemilikan (budak). Secara garis besar pengertian ini telah disepakati oleh para ulama" Islam, meskipun mereka masih berselisih pendapat tentang penerapan hukumannya ${ }^{1}$.

Maraknya kasus perzinaan yang terjadi dan terus meningkat pada kalangan anak-anak muda bahkan juga orang yang sudah menikah sangatlah meresahkan masyarakat. Karena hal itu dikhawatirkan akan merusak moral seseorang. Disamping rusaknya moral sesorang, dengan terjadinya kasus perzinaan yang terus meningkat ditakutkan akan menimbukan beberapa penyakit diantaranya HIV, AIDS, Sipilis dan lain sebagainya. Dan jika hal itu sudah terjadi, tentunya saja orang yang merasa dirugikan bukan hanya si pelaku, namun orang disekitarnya pasti merasa dirugikan. Apalagi jika si pelaku tertangkap tangan dalam melakukan perzinaan ataupun terkena penyakit dari apa yang telah dia lakukan, pasti keluarga, daerah, bahkan kerabat-kerabatnya akan merasa malu dan terbebani atas apa yang telah dia lakukan. Belum lagi kalau dari apa yang telah dia lakukan bisa menimbulkan lahirnya seseorang, tentunya orang yang lahir dari hubungan perzinaan akan merasa malu dan tidak jelas nasab serta keturunannya

Beberapa waktu yang lalu telah terjadi peristiwa diduga telah melakukan perbuatan Perzinahan yang dilakukan oleh dua orang anak manusia dengan predikat "Hajii", menurut keterangan dari beberapa orang yang telah melakukan penangkapan tersebut dan dari serangkaian keterangan peristiwa tersebut maka dilakukan proses penyelidikan dan penyidikan oleh Polres Pasuruan , didalam serangkaian kegiatan proses penyidikan, penyidik telah melakukan atau memintakan pendapat ahli hukum pidana akan tetapi dijelaskan bahwa perkara tersebut hanya melanggar norma agama dan tidak melanggar hukum pidana. Serta Penyidik tidak menemukan bukti awal maka sebagaimana saran dan pendapat hukum dari Pendapat Ahli Hukum maka dilakukannya tindakan yaitu dihentikan Penyidikannya atau SP3, akan tetapi pada tanggal 4 Juni 2014, Polres Pasuruan telah menerima surat Relaas Panggilan Pengadilan Negeri Bangil Nomor : 01/Pid.Pra/2014/PN.Bgl, tertanggal 4 Juni 2014 terkait adanya Gugatan Pra Peradilan sehubungan dengan adanya SP3 tersebut dan didalam Gugatan tersebut, disebutkan bahwa sebagai : Termohon Pra Peradilan adalah Polres Pasuruan dan sedangkan H Mursyid sebagai Pemohon, sehubungan dengan adanya Surat Perintah Penghentian Penyidikan (selanjutnya disingkat menjadi SP3) yang

\footnotetext{
${ }^{1}$ Zainudin Ali, Hukum Pidana Islam, Jakarta: Sinar Grafika, 2009, h. 37.
} 


\section{$\mathcal{H}$ urnal Negara dan Keadilan \\ p-ISSN 2302-7010 e-ISSN 2721-9801}

dilakukan oleh Polres Pasuruan, terkait tentang Tindak Pidana Zina yang dilakukan oleh Istri Pemohon dengan seorang laki laki lain di Villa Taman Dayu Blok Pasadena Hill Kec. Prigen Kab. Pasuruan .

Berdasarkan surat relaas dari Pengadilan Negeri Bangil tersebut, maka Kepala Kepolisian Resort Pasuruan, memerintahkan anggotanya, termasuk Penulis sebagai anggota Team yang bertugas di Bagian Sub Bag Hukum dengan Jabatan Ps. Paur Bankum dan mendapat perintah untuk mewakili Polres Pasuruan dan berdasarkan surat kuasa khusus untuk melaksanakan tugas tersebut, dari serangkaian kegiatan dalam proses Praperadilan selama 7 ( Tujuh ) hari kerja yang dilaksanakan di Pengadilan Negeri Bangil, dengan putusan yang berbunyi :

1. Mengabulkan Permohonan Pra Peradilan sebagian;

2. Memerintahkan kepada pihak termohon untuk melanjutkan penyidikan perkara pengaduan polisi bernomor : LP/61/III/2013/Jatim/Res-pas, tgl 2 Maret 2013;

3. Menolak permohonan Pemohon selain dan selebihnya

Ada satu hal yang sangat menarik perhatian bagi penulis terkait dari materi Gugatan tersebut adalah perkara Perzinahan yang di SP3 ( Surat Perintah Penghentian Penyidikan), dengan penafsiran sedemikian rupa tentang makna "Zina" sebagaimana dimaksud dalam Pasal 284 ayat (1) Kitab Undang Undang Hukum Pidana dan seterusnya disingkat dengan KUHP, bahwa perbuatan Perzinah an menekankan adanya persetubuhan atas dasar suka sama suka tanpa ada paksaan dan seseorang dapat dikatakan sebagai pelaku perzinahan apabila sudah melakukan persetubuhan.

Dalam penjelasan KUHP. Persetubuhan adalah : "Perpaduan antara anggota kelamin laki laki dan perempuan yang bisa dijalankan untuk mendapatkan anak, jadi anggota kelamin laki laki harus masuk kedalam anggota kelamin perempuan sehingga mengeluarkan air mani “.2

Dengan adanya Surat Edaran Mahkamah Agung No. 8 tahun 1980 yang ditujukan kepada Saudara Ketua Pengadilan Tinggi dan Saudara Ketua Pengadilan Negeri di Seluruh Indonesia tentang Putusan Mahkamah Agung Nomor :349 $\mathrm{K} / \mathrm{Kr} / 1980$, tanggal 26 Desember 1980 mengenai perkara Pasal 284 ayat (1) 1a KUHP, yang menegaskan bahwa tidak hanya pelaku saja yang dipersalahkan akan tetapi yang turut serta juga dipersalahkan.

Sehubungan dengan Putusan Mahkamah Agung tersebut, yang menggariskan keseimbangan dalam perlakukan hukum antara seorang suami dan seorang istri yang dituduhkan melakukan "Perbuatan zina" ex. Pasal 284 KUHP dengan Lampiran Putusan Mahkamah Agung No. 349.K/Kr./1980 tentang putusan Pengadilan Negeri Sukabumi yang berbunyi : menghukum terbukti bersalah melakukan kejahatan "laki laki yang beristri melakukan zina, dilakukan beberapa kali“, selanjutnya diajukan penuntutan kasasi oleh Terdakwa II (Cecep Iskandar bin Ajun ) akan tetapi Mahkamah Agung Menguatkan putusan pengadilan Negeri untuk selebihnya; menghukum penuntut kasasi tersebut untuk membayar segala biaya perkara dalam tingkat ini.

Seiring berjalannya waktu perkembangan hukum mengalami perubahan sejak adanya putusan Mahkamah Agung RI no. 854/Pid/1983 yang berbunyi sebagai berikut :"seorang laki-laki terbukti telah bersama sama dengan seorang

${ }^{2}$ Soesila, Penjelasan KUHP,Jakarta : Sinar Grafika, 1995, h.209 


\section{Hurnal Negara dan $\mathcal{X}$ eadilan \\ p-ISSN 2302-7010 e-ISSN 2721-9801}

perempuan dalam satu kamar, pada satu tempat tidur merupakan petunjuk bahwa laki-laki itu telah bersetubuh dengan perempuan tersebut",

Dengan demikian sudah tidak lagi berpedoman sebagaimana dimaksud dalam penjelasan KUHP yang menerangkan bahwa Persetubuhan adalah "Perpaduan antara anggota kelamin laki laki dan perempuan yang bisa dijalankan untuk mendapatkan anak, jadi anggota kelamin laki laki harus masuk kedalam anggota kelamin perempuan sehingga mengeluarkan air mani“‘3, akan tetapi pada putusan Pra Peradilan Nomor : 01/Pid.Pra/2014/PN.Bgl, tertanggal 16 Juni 2014, banyak mengalami perubahan makna yaitu tidak lagi mengacu pada satu kamar dan satu tempat tidur lagi, melainkan menjadi "seorang laki laki terbukti telah bersama sama dengan seorang perempuan tanpa ada ikatan perkawinan yang sah dan bukan suami istri, dalam satu rumah (terdiri : 2 ruang kamar tidur, 1 ruang kamar mandi, 1 ruang makan dan 1 ruang tamu) merupakan petunjuk bahwa laki laki tersebut"sudah dapat dianggap"telah bersetubuh dengan perempuan tersebut, sehingga pemaknaan tentang perbuatan perzinahan mengalami pergeseran sejak adanya Surat Edaran Mahkamah Agung Nomor 8 Tahun 1980 hingga Putusan Mahkamah Agung nomor 854.K/Pid/1983 tersebut .

\section{METODE PENELITIAN}

Dalam penelitian ini akan melakukan pengkajian terhadap putusan hakim pra peradilan pengadilan negeri bangil nomor : 01/Pid.Pra/2014/Pn.Bgl tgl 16 juni 2014 Terkait surat perintah Penghentian Penyidikan Tindak Pidana Zina jo Pasal 284 KUHP, dengan peraturan perundang - undangan terutama Undang - Undang Republik Indonesia Nomor 1 Tahun 1946 tentang Kitab Undang Undang Hukum Pidana yang membahas tentang Tindak Pidana Perzinahan Dengan penggunaan penelitian yuridis nomatif ini, permasalahan diatas akan dikaji melalui sejumlah peraturan perundang-undangan dan teori-teori yang berkaitan dengan permasalahan tersebut.

\section{PEMBAHASAN}

Dalam Putusan Pra Peradilan dengan Nomor : 01/Pid.Pra/2014/PN.BIL, tertanggal 16 Juni 2014, yang diucapkan dalam sidang yang terbuka untuk umum oleh HARIS BUDIARSO,S.H.,M.H, Hakim pada Pengadilan Negri Bangil dengan dibantu oleh SUWANDI,S.H.,M.H sebagai Panitera dengan dihadiri oleh Kuasa Hukum Pemohondan Kuasa Hukum Termohon, dengan bunyi Putusan sebagai berikut :

\section{DALAM EKSEPSI}

\section{MENGADILI :}

1. Menolak eksepsi Termohon

\section{DALAM POKOK PERKARA}

1. Mengabulkan Permohonan Pra Peradilan Pemohon sebagian;

2. Memerintahkan kepada pihak Termohon untuk melanjutkan Penyidikan perkara pengaduan polisi bernomor : LP/61/III/2013/Jatim/res.Pas, Tanggal 2 Maret 2013.

3. Menolak permohonan Permohon selain dan selebihnya

${ }^{3}$ Soesila, Penjelasan KUHP,Jakarta : Sinar Grafika, 1995, h.209 


\section{$\mathcal{H}$ urnal Negara dan Keadilan \\ p-ISSN 2302-7010 e-ISSN 2721-9801}

Putusan hakim Pra Peradilan merupakan puncak dari suatu perkara yang sedang diperiksa dan diadili oleh Hakim tersebut. Oleh karena itu, tentu saja Hakim membuat keputusan harus memperhatikan segala aspek didalamnya, mulai dari perlunya kehati-hatian, dihindari sedikit mungkin ketidakcermatan, baik yang bersifat formal maupun yang bersifat materiil, sampai dengan adanya kecakapan teknik membuatnya. Jika hal-hal negatif dapat dihindari, tentu saja diharapkan dalam diri hakim lahir, tumbuh, dan berkembang adanya sikap atau sifat kepuasan moral jika kemudian putusannya itu dapat menjadi tolak ukur untuk perkara yang sama, atau dapat menjadi bahan referensi bagi kalangan teoritisi maupun kalangan praktisi hukum serta kepuasan nurani sendiri jika putusannya dikuatkan dan tidak dibatalkan oleh pengadilan yang lebih tinggi.

Dalam sidang Pra Peradilan di Pengadilan Negeri Bangil terkait Surat Perintah Penghentian Penyidikan ( SP3 ) tentang Tindak Pidana Perzinahan, sebagaimana pada point angka satu bahwa Hakim telah mengabulkan Permohonan Pra Peradilan pemohonan sebagian dengan pertimbangan hukum yang digunakan adalah :

\section{a. Pertimbangan tentang Visum Et Repertum}

Sebagaimana dimaksud dalam Pasal 184 KUHAP tentang adanya alat bukti , maka Visum Et Repertum adalah salah satu alat bukti yang sah berupa "Surat" dan juga "Keterangan ahli". Visum Et Repertum merupakan suatu laporan tertulis dari dokter ( ahli ) yang dibuat berdasarkan sumpah dan Jabatannya, perihal apa yang dilihat dan yang ditemukan atas bukti hidup, mayat atau fisik atau barang bukti lain, kemudian dilakukan pemeriksaan berdasarkan pengetahuan yang sebaik-baiknya. Atas dasar itu selanjutnya diambil kesimpulan, yang juga merupakan pendapat dari seorang ahli atau kesaksian ( ahli ) secara tertulis.

Oleh karena itu Visum Et Repertum semata-mata hanya dibuat agar suatu perkara pidana menjadi jelas dan hanya berguna bagi kepentingan pemeriksaan dan untuk keadilan serta diperuntukan bagi peradilan, Visum Et Repertum tidaklah dibuat atau diterbitkan untuk kepentingan yang lain, maka itu didalam setiap pembuatan Visum Et Repertum selalu didahului dengan perkataan "Pro Yustitia" atau "Demi Keadilan.

Pertimbangan Hakim Pra Peradilan, bahwa setelah dilakukan penangkapan terhadap dua orang yang bernama Misbahul Munir dan $\mathrm{Hj}$. Asrukhan tersebut kemudian Unit PPA Polres Pasuruan yang melakukan penyelidikan serta penyidikan terhadap pengaduan Pemohon, ( diakui oleh saksi Ditrmei Hartono petugas kepolisian Resort Pasuruan Unit PPA ) kemudian yang menjadi permasalahan pihak Termohon tidak langsung melakukan visum ( vide T-25 ) terhadap dua orang yang bernama Misbahul Munir dan $\mathrm{Hj}$. Asrukhan tersebut dengan alasan sudah malam hari dan harus kedokter kandungan akan tetapi pihak Termohon tidak cermat dalam memahami sebuah bukti yang dapat hilang jikalau sudah melebihi jangka waktu yang cukup lama dimana visum tersebut dilakukan keesokan harinya sehingga dapat dikatakan ada kesempatan yang cukup bagi seseorang yang disangka melakukan sebuah tindak pidana menghilangkan buktibukti tersebut dan 'tindakan tersebut diatas menurut hakim adalah ketidakcekatan serta kurang responsifnya Termohon dalam usaha untuk menambah atau melengkapi bukti-bukti sehingga mendapat hasil yang sia-sia atas bukti yang didapat. 


\section{Zurnal Negara dan $\mathcal{X}$ eadilan \\ p-ISSN 2302-7010 e-ISSN 2721-9801}

Pertimbangan Hukum oleh Hakim adalah tidak dengan segera dilakukan Visum et Repertum sehingga mengakibatkan hilangnya sebuah alat bukti melalui alat bukti surat yang berupa Visum et Repertum ,Permintaan Visum Et Repertum dilakukan pada tanggal 2 Maret 2013 pada malam hari tidak bisa dilakukan karena tidak adanya dokter ahli kandungan dan baru bisa dimintakan pada esok harinya pada tanggal 3 Maret 2013 dan belum sampai 1 X 24 jam, kalau Visum et Repertum dilakukan dengan tujuan untuk melihat luka sobek pada kemaluan perempuan yang sudah berusia 40 Tahun keatas akibat persetubuhan, apalagi perempuan tersebut sudah mempunyai beberapa anak maka akan sulit untuk didapat akan tetapi apabila dilakukan Visum et Repertum dengan tujuan apakah telah dilakukan persetubuhan maka akan kedapatan sperma dari laki-laki yang menyetubuhi yang berada didalam rahim wanita dan Sperma dapat hidup dan membuahi dalam waktu antara 2 sampai 3 Hari setelah enjakulasi, jadi kalau dikatakan bahwa tidak Reponsif atau cekatan adalah tidak benar dan tidak mendasar sedangkan hasil Visum et Repertum yang dinyatakan oleh pihak Rumah Sakit Umum , dengan hasil "Negatif " dengan maksud tidak adanya sperma yang tertinggal didalam Rahim wanita maka menunjukan bahwa tidak / belum adanya bentuk persetubuhan ${ }^{4}$.

Pertimbangan Hukum oleh Hakim Pengadilan Negeri Bangil, hanya terfokus pada adanya Visum Et Repertum saja dan tidak melihat bukti lain yang berupa celana dalam, padahal seorang laki-laki atau perempuan setelah melakukan persetubuhan maka apabila kemudian memakai celana dalam maka ada terlihat bercak basah yang akan menempel dicelana dalam tersebut dan bercak cairan tersebut adalah sisa cairan yang keluar akibat persetubuhan yang disebut "Madi" , kejahatan A Susila tanpa ada bukti persetubuhan maka termasuk Perbuatan Cabul dan kalau persetubuhan disertai bentuk kekerasan atau ancaman kekerasan atau dalam keadaan tidak berdaya maka termasuk Perbuatan Pemerkosaan

Dengan tidak adanya sperma didalam kandung Rahim ada dua kemungkinan yaitu :

1) Belum terjadinya persetubuhan ( masuknya alat kelamin laki laki kedalam lubang tempat keluarnya anak ) antara laki laki dan perempuan yang melakukan perbuatan Zina.

2) Tertangkap tangan, sehingga belum selesainya secara sempurna perbuatan Zina tersebut

b. Pertimbangan Tentang Tempat Kejadian Perkara.

Bahwa pihak Termohon ( Penyidik Polres Pasuruan ) berpandangan sempit berkaitan dengan adanya Yurisprudensi Mahkamah Agung RI sebagaimana dalam putusan MA RI No. Perkara. 845.K/Pid/1993 yang menyatakan“ Seorang laki-laki terbukti telah bersama-sama dengan seorang perempuan dalam 1 (satu) kamar merupakan petunjuk bahwa laki-laki itu telah bersetubuh dengan perempuan tersebut " dimana Termohon terjebak dalam kamar " yang menjadi pertanyaan hakim apakah persetubuhan hanya dapat dilakukan dikamar, jikalau dirumah tersebut tidak terdapat kamar akan tetapi ada bukti Kasur atau alas tempat tidur disebuah ruangan bukan kamar dimana persetubuhan dilakukan antara laki-laki dan perempuan yang bukan pasangan sah dimana salah satu dari pasangan

\section{Yogyakarta}

${ }^{4}$ Imelda Fitri. 2017. Lebih Dekat Dengan Sistem Reproduksi Wanita. Gosyeh Publising. 


\section{$\mathcal{H}$ urnal Negara dan Keadilan \\ p-ISSN 2302-7010 e-ISSN 2721-9801}

tersebut mempunyai ikatan pernikahan dengan pihak lain, apakah hal tersebut akan menjadikan tindakan perzinahan menjadi tidak terbukti dan atau kurang cukup bukti.

Pertimbangan Hukum oleh Hakim Pengadilan Negeri Bangil adalah bahwa disebutkan alamat kejadian adalah " Perumahan Taman Dayu Blok Pasadena Hill Prigen Pasuruan " setidak-tidaknya adalah bentuk rumah dan bukan kamar dan sedangkan Perumahan Taman Dayu Blok Pasadena Hill Prigen Pasuruan adalah rumah yang terdiri dari : 2 ruang kamar tidur, 1 ruang kamar mandi, 1 ruang makan dan 1 ruang tamu), makna dari Yurisprudensi MARI No. 854/Pid/1983 harus dibaca di mana tempat yang diduga untuk melakukan perzinahan adalah sebuah kamar bukan sebuah rumah yang terdiri dari beberapa kamar dalam arti tempat yang disebut sebagai " kamar " atau sebuah " ruangan " tersebut merupakan satu-satunya tempat yang memang diyakini sebagai tempat melakukan perbuatan yang diduga sebagai " zina " dan keyakinan tentang hal tersebut timbul apabila memang tidak menimbulkan suatu keyakinan lain bahwa Terdakwa /Tersangka sebenarnya tidak melakukan hal yang dituduhkan sehingga dapat terhindar dari sekedar fitnah atau kecurigaan tanpa dasar. Dalam kasus ini sesuai fakta yang terungkap di persidangan ternyata di " kamar " atau "ruangan " yang diduga sebagai tempat " perzinahan " tersebut masih ada " kamar " atau " ruangan " lain, sehingga menimbulkan keraguan keyakinan bahwa antaraTerdakwa / Tersangka dan kawan zinanya patut untuk dituduh melakukan hal tersebut, dan saat dilakukan penangkapan terhadap dua orang yang berlainan jernis tersebut tidak berada didalam satu ruangan akan tetapi yang perempuan berada didalam kamar dan sedangkan laki laki berada diruang tamu dan membukakan pintu.

Bahwa pihak termohon tidak jeli dan tidak Reponsif atas perkara tersebut, pihak Termohon sudah mengetahui bahwa ada dua orang yang bernama Misbahul Munir dan $\mathrm{Hj}$. Asrukhan " bukan pasangan yang sah " dimana $\mathrm{Hj}$. Asrukhan tersebut adalah istri sah dari $\mathrm{H}$ Mursyid tentunya dengan pengetahuan yang cukup tersebut dapat diperkirakan jikalau ada seorang berlainan jenis kelamin berduaan dalam sebuah rumah bukan pasangan yang sah dan tidak ada orang lain selain dua orang yang berlainan jenis kelamin maka dapat disimpulkan maka kedua orang tersebut telah melakukan perzinahan, dapat diketahui di Kabupaten Pasuruan adalah kota agamis, dimana norma agama menjadi panutan dan dikedepankan oleh masyarakat Kabupaten Pasuruan dan tentunya hal tersebut adalah perbuatan yang sangat tercelah dan bertentangan dengan nilai-nilai / norma-norma yang hidup dalam masyarakat serta agama, apalagi salah satu dari orang yang berada didalam satu rumah tersebut adalah $\mathrm{Hj}$. Asrukhan tentunya sudah paham ajaran agama yang didapat.

Pertimbangan Hukum oleh Hakim Pengadilan Negeri Bangil adalah bahwa dua orang yang berlainan jenis kelamin dan bukan pasangan yang sah dimana salah satu pasangan diketahui telah mempunyai seorang suami dan tidak ada orang lain selain dua orang tersebut maka dapat disimpulkan maka kedua orang tersebut " Telah " atau " bisa " dikatakan telah melakukan Perzinahan, dengan menyimpulkan telah melakukan perzinahan tanpa melakukan pembuktian dengan cara dilakukan visum et repertum oleh ahli kandungan ( untuk diketahui apakah ada sperma yang tertinggal dalam rahim setelah adanya persetubuhan atau perzinahan itu dilakukan ) maka kesimpulan tersebut menjadi kabur dan tidak 


\section{Hurnal Negara dan $\mathcal{X}$ eadilan \\ p-ISSN 2302-7010 e-ISSN 2721-9801}

mendasar sama sekali. Serta jikalau dikaitkan dengan Kabupaten Pasuruan yang merupakan kota agamis, dimana norma agama menjadi panutan dan dikedepankan oleh masyarakat Kabupaten Pasuruan dan tentunya hal tersebut adalah perbuatan yang sangat tercelah dan bertentangan dengan nilai agama, apalagi salah satu dari orang yang berada didalam satu rumah tersebut adalah seorang Haji, maka jelas apa yang terjadi didalam rumah di Perumahan Taman Dayu Blok Pasadena Hill Prigen kabupaten Pasuruan, adalah merupakan pelanggaran norma agama dan bukan atau tidak melanggar norma hukum pidana

Bahwa seharusnya dalam rangkaian kejadian tersebut Termohon jeli dimana jikalau seorang tamu datang ketempat seseorang apakah pemilik rumah hanya menggunakan sarung dan kaos, jika seseorang membicarakan masalah bisnis apakah mungkin menemui rekan bisnis menggunakan pakaian yang tidak pantas dan kurang sopan, selain itu juga adanya perbuatan Misbahul Munir berkata bohong ketika menyatakan bahwa wanita yang bersamanya adalah istrinya padahal dan dapat dibuktikan kebenarannya wanita yang Bersama Misbahul Munir adalah istri orang lain dan bukan pasangan yang sah.

Pertimbangan Hukum oleh Hakim Pengadilan Negeri Bangil adalah bahwa apa dengan menggunakan sarung dan kaos untuk memenuhi rekan bisnis dianggap sudah tidak pantas dan tidak sopan, dan kalau dilihat rekan bisnis yang bagaimana sehingga menggunakan kaos dan sarung sudah dinggap tidak sopan , sebagaimana Ahli Dr. H. Setyono,S.H.,M.H berpendapat bahwa apa yang terjadi dengan Sdr. Misbahul Munirdan $\mathrm{Hj}$. Asrukhan tidak memenuhi unsur tindak pidana, serta tidak melanggar norma-norma hukum pidana melainkan telah melanggar norma hukum agama.

\section{c. Pertimbangan Tentang Pembuktian}

Sejarah perkembangan hukum acara pidana menunjukkan bahwa ada beberapa system atau teori untuk membuktikan perbuatan yang didakwakan. Sistem atau teori pembuktian ini bervariasi menurut waktu dan tempat, antara lain:

a. Sistem/Teori Pembuktian berdasarkan Undang-Undang secara Positif ( Positive Wettelijk Bewijstheorie )

b. Sistem atau Teori Pembuktian berdasarkan Keyakinan Hakim Melulu

c. Sistem/Teori Pembuktian berdasarkan Keyakinan Hakim atas Alasan yang Logis ( Laconviction Raisonnee )

d. Sistem atau Teori Pembuktian berdasarkan Undang-Undang secara Negatif ( Negatief Wettelijk $)^{5}$

Bahwa berdasarkan Pasal 184 ayat (1) KUHAP dan Pasal 183 KUHAP sebagaiman dimaksud tersebut diatas, setidak-tidaknya ada dua atau tiga alat bukti dalam perkara ini yang memenuhi perkara ini :

a. Keterangan Saksi ;

b. Keterangan Ahli dan

c. Petunjuk.

Dan pendapat M Yahya Harahap dalam bukunya " PembahasanPembahasan. Dan penerapan KUHAP, Edisi kedua, Penerbit PT Sinar Grafika

${ }^{5}$ Andi Hamzah. 2008. Hukum Acara Pidana Indonesia. Edisi Kedua. Sinar Grafika Jakarta . h. 249 


\section{$\mathcal{H}$ urnal Negara dan Keadilan \\ p-ISSN 2302-7010 e-ISSN 2721-9801}

Tahun 1985, Hal 283 - 284 menyebutkan “, untuk membuktikan kesalahan Terdakwa / Tersangka harus merupakan :

a. Penjumlahan dari sekurang-kurangnya seorang saksi ditambah dengan seorang ahli

b. Atau bisa juga, penjumlahan dua alat bukti itu berupa keterangan dua orang saksi yang saling bersesuaian dan saling menguatkan, maupun penggabungan antara keterangan terdakwa jelas terdapat saling persesuaian. $^{6}$

Sebenarnya pendapat M Yahya Harahap dalam bukunya " PembahasanPembahasan. Dan penerapan KUHAP, Edisi kedua, Penerbit PT Sinar Grafika Tahun 1985, Hal 283 - 284 pada point : Penjumlahan dari sekurang-kurangnya seorang saksi ditambah dengan seorang ahli atau surat maupun petunjuk, dengan ketentuan penjumlahan kedua alat bukti tersebut harus "saling bersesuaian" , " saling menguatkan " dan tidak saling bertentangan antara satu dengan yang lain ;

Dengan telah melakukan penjumlahan alat bukti yang sah dan Hakim Pra Peradilan sudah cukup memberikan bahan dimana sudah ada alat bukti yang cukup berupa : saksi, ahli dan petunjuk dalam dugaan perzinahan tersebut, sehingga menurut Hakim sudah dianggap perkara tersebut bukan menjadi terhenti oleh karena kurangnya alat bukti, dalil penghentian penyidikan oleh Termohon yang tidak cukup bukti, tidak benar dan tidak berdasar hukum, karena bukti-bukti yang telah disajikan sudah cukup untuk dijadikan patokan dasar dalam menindak lanjuti tindak pidana ke tahap penuntutan , Bahwa berdasarkan fakta-fakta yang muncul dan terungkap dipersidangan adalah : ada satu alat bukti "Surat " berupa "Visum Et Repertum “ yang tidak dianggap dan diabaikan oleh Hakim Pra Peradilan, sehingga dari beberapa alat bukti yang ada ternyata ada salah satu alat bukti yang tidak bersesuai dengan alat bukti yang lain, maka dengan adanya alat bukti berupa " petunjuk " tersebut maka Pertimbangan Putusan Hakim menjadi tidak sempurna atau "Sumir "

Dalam mengurai alat bukti petunjuk antara keterangan saksi, dan keterangan ahli, ada tidak persesuaian dengan alat bukti surat berupa " Visum Et Repertum " yang dikeluarkan oleh Rumah Sakit Umum Bangil dengan Nomor : 180/0563/424.079/2013, tanggal 14 Maret 2013.

Sebagaimana dimaksud dalam Pasal 183 KUHP yang mengatur sebagai berikut :

" Hakim tidak boleh menjatuhkan pidana kepada seseorang, kecuali apabila dengan sekurang-kuranya dua alat bukti yang sah ia memperoleh keyakinan bahwa suatu tidak pidana benar-benar terjadi dan bahwa terdakwalah yang bersalah melakukannya "

Dan alat bukti yang sah diatur dalam Pasal 184 KUHP, disertai dengan keyakinan Hakim Praperadilan yang diperoleh dari alat-alat bukti tersebut, sehingga Hakim Pra Peradilan Negeri Bangil : "Memerintahkan kepada pihak Termohon untuk melanjutkan Penyidikan perkara Pengaduan Polisi Nomor : LP/61/III/2013/Jatim/Res.Pas. tanggal 2 Maret 2013.

Sebagaimana dimaksud dalam Pasal 284 ayat (1) Kitab Undang Undang Hukum Pidana dan seterusnya disingkat dengan KUHP, bahwa perbuatan

${ }^{6}$ M. Yahya Harapan. Pembahasan-Pembahasan dan Penerapan KUHAP. Edisi Kedua. PT. Sinar Grafika. 1985. h. 283-284 


\section{Zurnal Negara dan $\mathcal{X}$ eadilan \\ p-ISSN 2302-7010 e-ISSN 2721-9801}

Perzinahan menekankan adanya persetubuhan atas dasar suka sama suka tanpa ada paksaan dan diketahui salah satu atau keduanya telah mempunyai pasangan , seseorang dapat dikatakan sebagai pelaku perzinahan apabila sudah melakukan persetubuhan.

Menurut Soesilo dalam penjelasan KUHP. Persetubuhan adalah : “ Perpaduan antara anggota kelamin laki laki dan perempuan yang bisa dijalankan untuk mendapatkan anak, jadi anggota kelamin laki laki harus masuk kedalam anggota kelamin perempuan sehingga mengeluarkan air mani “. 7

Terkait dengan berlakunya Pasal 284 ayat (1) KUHP ini juga berlaku adanya Surat Edaran Mahkamah Agung No. 8 tahun 1980 yang ditujukan kepada Saudara Ketua Pengadilan Tinggi dan Saudara Ketua Pengadilan Negeri di Seluruh Indonesia tentang Putusan Mahkamah Agung Nomor : $349 \mathrm{~K} / \mathrm{Kr} / 1980$ tanggal 26 Desember 1980 mengenai perkara Pasal 284 ayat (1) 1a KUHP, Sehubungan dengan Putusan Mahkamah Agung tersebut, yang menggariskan keseimbangan dalam perlakukan hukum antara seorang suami dan seorang istri yang dituduhkan melakukan "Perbuatan zina" ex. Pasal 284 KUHP dengan Lampiran Putusan Mahkamah Agung No. 349.K/Kr./1980 tentang putusan Pengadilan Negeri Sukabumi yang berbunyi : menghukum terbukti bersalah melakukan kejahatan " laki laki yang beristri melakukan zina, dilakukan beberapa kali “, selanjutnya diajukan penuntutan kasasi oleh Terdakwa II (Cecep Iskandar bin Ajun ) akan tetapi Mahkamah Agung Menguatkan putusan pengadilan Negeri untuk selebihnya; menghukum penuntut kasasi tersebut untuk membayar segala biaya perkara dalam tingkat ini.

Seiring berjalannya waktu perkembangan hukum mengalami perubahan sejak adanya putusan Mahkamah Agung RI no. 854/Pid/1983 yang mengatur sebagai berikut :“ seorang laki-laki terbukti telah bersama sama dengan seorang perempuan dalam satu kamar, pada satu tempat tidur merupakan petunjuk bahwa laki-laki itu telah bersetubuh dengan perempuan tersebut",

Dengan demikian sudah tidak lagi berpedoman sebagaimana dimaksud dalam penjelasan KUHP menurut Soesilo ( 1995 ; 209 ) yang menerangkan bahwa Persetubuhan adalah "Perpaduan antara anggota kelamin laki laki dan perempuan yang bisa dijalankan untuk mendapatkan anak, jadi anggota kelamin laki laki harus masuk kedalam anggota kelamin perempuan sehingga mengeluarkan air "mani", akan tetapi pada putusan Praperadilan Nomor : 01/Pid.Pra/2014/PN.Bgl, tertanggal 16 Juni 2014, banyak mengalami perubahan makna yaitu tidak lagi mengacu pada satu kamar dan satu tempat tidur lagi, melainkan menjadi "seorang laki laki terbukti telah bersama sama dengan seorang perempuan tanpa ada ikatan perkawinan yang syah dan bukan suami istri, dalam satu rumah (terdiri : 2 ruang kamar tidur, 1 ruang kamar mandi, 1 ruang makan dan 1 ruang tamu ) merupakan petunjuk bahwa laki laki tersebut "sudah dapat dianggap" telah bersetubuh dengan perempuan tersebut, sehingga pemaknaan tentang perbuatan perzinahan mengalami pergeseran sejak adanya Surat Edaran Mahkamah Agung Nomor 8 Tahun 1980 hingga Putusan Mahkamah Agung Nomor 854.K/Pid/1983 tersebut . ${ }^{8}$

Secara normative hal yang terpenting adalah tetap harus ada pembuktian , apakah sebelumnya telah terjadi persetubuhan antara Sdr. MIsbahul Munir dan $\mathrm{Hj}$.

${ }^{7}$ Soesilo, 1995. Penjelasan KUHP. h 209

${ }^{8} \mathrm{Ibid}$ 


\section{$\mathcal{H}$ urnal Negara dan Keadilan \\ p-ISSN 2302-7010 e-ISSN 2721-9801}

Asrukhan atau belum terjadinya persetubuhan, dan tidak hanya sekedar berasumsi bahwa perempuan dan laki laki yang bukan suami istri dalam satu rumah sudah merupakan atau "sudah bisa dianggap " bersetubuh tanpa harus ada pembuktian tentang persetubuhan itu sendiri.

Dan sebagaimana dimaksud dalam Pasal 1 ayat (1) KUHP yang berbunyi : Suatu perbuatan tidak dapat dipidana, kecuali berdasarkan ketentuan perundangundangan pidana yang telah ada, sebelum perbuatan itu terjadi .

Dengan adanya pergeseran dan perluasan makna zina sebagaimana yang dimaksud dalam Pasal 284 KUHP hingga putusan Praperadilan, adalah suatu proses perkembangan hukum dengan tujuan adanya pembaharuan / perbaikan / penyempurnaan suatu hukum .Disamping itu, selain sebagai penyempurna atau pelengkap, segala unsur hukum yang baru itu dapat pula berfungsi sebagai penganti unsur-unsur lama yang kiranya sudah tidak mungkin dapat dipertahankan lebih lama, mengingat kondisinya yang sudah tidak selaras lagi dengan situasi perkembangan zaman.

Pembaruan dibidang hukum sangat diperlukan dalam setiap perkembangannya, dengan maksud dan tujuannya adalah untuk mewujudkan kepatian bagi masyarakat, maka tentu saja setiap hukum yang ditetapkan selalu diusahakan dan diselaraskan penetapannya agar dapat berlaku selama dan selanggeng mungkin.

\section{KESIMPULAN}

Pertimbangan Hukum yang dilakukan oleh Hakim Pengadilan Negri Bangil, Terhadap Perkara Pra Peradilan Dengan Nomor : 01/Pid.Pra/2014/PN.Bgl, tertanggal 16 Juni 2014 , terkait Surat Perintah Penghentian Penyidikan tentang Tindak Pidana Perzinahan, Bahwa Majelis Hakim Pengadilan Negeri Bangil dalam pertimbangan putusannya kurang cermat dan tidak memperhatikan secara jelas, syarat-syarat Formil maupun syarat-syarat Materiil maupun unsur-unsur tindak pidana perzinahan , sehingga putusan menjadi sumir , Terbukti hasil “ Visum Et Repertum “ yang dikeluarkan oleh Rumah Sakit Umum Bangil dengan Nomor : 180/0563/424.079/2013, tanggal 14 Maret 2013 . dinyatakan Negative / tidak terbukti dan Hakim hanya berpedoman pada fakta bahwa adanya laki - laki dan perempuan berada didalam satu rumah dan berlainan tempat ( Kamar dan ruang tamu ) sudah bisa dianggap telah melaksanakan persetubuhan . Hal ini dipedomani oleh Majelis Hakim Pengadilan Negeri Bangil karena adanya Yurisprudensi MahkamahAgung RI sebagaimanadalamputusan MA RI No. Perkara.845.K/Pid/1993 .

Dengan adanya putusan hakim Pra Peradilan Pengadilan Negeri Bangil Nomor : 01/Pid.Pra/2014/PN.Bgl, Tgl. 16 Juni 2014 Tentang Tindak :Pidana Zina dan Yurisprudensi MA RI No. 854/Pid/1983, adanya perbedaaan yang sangat mencolok sekali akhirnya menimbulkan pemikiran yang keragu - raguan , kekaburan atau ketidakjelasan, apakah perbuatan perzinahan tersebut benar benar sudah terjadi atau belum terjadi. 


\section{Hurnal Negara dan $\mathcal{X}$ eadilan \\ p-ISSN 2302-7010 e-ISSN 2721-9801}

\section{Buku}

\section{DAFTAR PUSTAKA}

Alfitrah. 2011. Hukum Pembuktian dalam beracara Pidana, Perdata dan Korupsi di Indonesia edisi revisi. Raih Asa Sukses. Pamulang

Andi Hamzah. 2008. Hukum Acara Pidana Indonesia. Edisi Kedua.Sinar Grafika. Jakarta

HMA Kuffal. 2002. Penerapan KUHP dalam Praktik Hukum edisi Revisi. UMM Malang

Imelda Fitri. 2017. Lebih Dekat dengan Sistem Reproduksi Wanita. Gosyeh Publising. Yogyakarta.

Luhut MP Pangaribuan.2013. Hukum Acara Pidana Surat Resmi Advokat di Pengadilan. Papas Sinar Sinani. Jakarta.

M Yahya Harahap. 2000. Pembahasan Permasalahan dan Penerapan KUHP ( Penyidikan dan Penuntutan ) edisi Kedua.Sinar Gafika. Jakarta

M Yahya Harahap.2000 Pembahasan Permasalahan dan Penerapan KUHP ( Pemeriksaan Sidang Pengadilan, Banding, Kasi, dan Peinjauan Kembali ) edsi Kedua. Jakarta.

Marzuki, Peter Mahmud,2007, Penelitian Hukum, Kencana Prenada Media Group, Jakarta

Munir Fuady. 2012. Teory Hukum Pembuktian Pidana dan Perdata. PT Gita Aditya Bhakti Bandung.Jakarta.

Moeljatno.2009, Asas-Asas Hukum Pidana, Rineka Cipta, Jakarta

Rachmat Trijono. 2016. Kamus Hukum .Pustaka Kemang.Jakarta

Suratman. H Philipus Dilla. 2012. Metode Penelitian Hukum. Alfa Beta Bandug. Malang

Soekanto, Soerjono \& Sri Mamudji, 2009, Penelitian Hukum Normatif Suatu Tinjauan Singkat, Raja grafindo Persada, Jakarta

Soeparmono.2015. Praperadilan Dan Penggabungan Perkara Gugatan Ganti Kerugian Dalam KUHAP. CV.Mandar Maju. Bandung.

Sunggono, Bambang. 1996. Metodologi Penelitian Hukum. Raja Grafindo Persada Jakarta.

Mabes Polri .1987. Himpunan Juklak dan Juknis tentang Proses Penyidikan Tindak Pidana . Jakarta.

Fakultas Hukum Universitas Merdeka Pasuruan..2014 Buku Pedoman Penulisan Proposal Dan Skripsi. Pasuruan

Undang-undang Dan Peraturan :

Kitab Undang-undang Hukum Pidana ( KUHP) dengan Penjelasannya oleh R. Sugadhi

Kitab Undang-undang Hukum Pidana ( KUHP) dengan Penjelasannya oleh R. Soesilo

Kitab Undang-undang Hukum Pidana ( KUHP ) Divisi Buku Perguruan Tinggi oleh R Soerodibroto

Kitab Undang-Undang Hukum Acara Pidana ( KUHAP )

Surat Edaran Mahkamah Agung Nomor 8 tahun 1980

Putusan Mahkamah Agung RI Nomor : 854/Pid/1983

Putusan Mahkamah Agung RI Nomor: 561.K/Pid/1982. Tgl 2Juli 1983

Putusan Mahkamah Agung RI Nomor : 93.KJiCr/1976. Tgl 19 Npember 1977

Putusan Mahkamah Agung RI Nomor : 52.K/Kr/1953. Tgl 19 Maret 1955 


\section{Jurnal Negara dan $\mathcal{X}$ eadilan \\ p-ISSN 2302-7010 e-ISSN 2721-9801}

\section{Internet}

http://fakta-inspiratif.blogspot.co.id/2015/10/peran-dan-fungsi-pengadilantingkat-pertama.html. ,

( https://idm.wikipedia.org/iki/Pengadilantinggi ) 